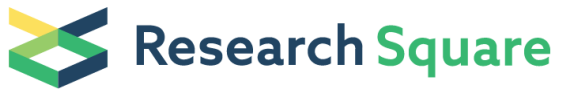 \\ Preprints are preliminary reports that have not undergone peer review. \\ They should not be considered conclusive, used to inform clinical practice, \\ or referenced by the media as validated information.
}

\section{Satellite Cells and Neuromuscular Spindles in Long Term Denervated Skeletal Muscles}

\section{André Luis Shinohara}

Universidade de Sao Paulo Faculdade de Odontologia de Bauru

\section{Carina Melo}

Universidade de São Paulo Faculdade de Odontologia de Bauru: Universidade de Sao Paulo Faculdade de Odontologia de Bauru

\section{Farooque Ahmed}

Universidade de São Paulo Faculdade de Odontologia de Bauru: Universidade de Sao Paulo Faculdade de Odontologia de Bauru

\section{Beatriz Sangalette ( $\sim$ beatrizsangalette@usp.br)}

Universidade de São Paulo Faculdade de Odontologia de Bauru: Universidade de Sao Paulo Faculdade de Odontologia de Bauru https://orcid.org/0000-0001-7030-8885

\section{João Vitor Shindo}

Universidade de São Paulo Faculdade de Odontologia de Bauru: Universidade de Sao Paulo Faculdade de Odontologia de Bauru

\section{Gustavo Toledo}

Universidade Estadual do Norte do Paraná: Universidade Estadual do Norte do Parana

\section{Claudia bighetti}

University of Texas at Dallas

\section{Mariza matsumoto}

Universidade Estadual Paulista Julio de Mesquita Filho Faculdade de Odontologia de Aracatuba Campus de Aracatuba

\section{Rogério Buchaim}

Universidade de São Paulo Faculdade de Odontologia de Bauru: Universidade de Sao Paulo Faculdade de Odontologia de Bauru

\section{Jesus Carlos Andreo}

Universidade de São Paulo Faculdade de Odontologia de Bauru: Universidade de Sao Paulo Faculdade de Odontologia de Bauru

\section{Antonio Rodrigues}

Universidade de São Paulo Faculdade de Odontologia de Bauru: Universidade de Sao Paulo Faculdade de Odontologia de Bauru

\section{Research}

Keywords: Satellite cells, Skeletal muscle, Neuromuscular spindles, Denervation, Reinnervation 
Posted Date: August 10th, 2021

DOI: https://doi.org/10.21203/rs.3.rs-773539/v1

License: (c) (i) This work is licensed under a Creative Commons Attribution 4.0 International License. Read Full License 


\section{Abstract}

Satellite cells (SC) are quiescent cell located between the sarcolemma and basal lamina of the skeletal muscle fibers. The SC can get activated contributing to regeneration and/or growth of muscle. The neuromuscular spindles are mechanoreceptors located within the skeletal muscle and are considered as contractile regulatory unit. It is composed of intrafusal muscle fibers (IF), surrounded by a sheath and is parallel to extrafusal fibers. Denervation cause changes in skeletal muscles both in the SC and neuromuscular spindles. This study analyzed quantitatively the IF and SC in Wistar rats denervated for long period. The animals were divided into normal and denervated groups. The soleus and extensor longus digitorum longus were denervated experimentally during periods of $0,12,16,19,30$ and 38 weeks. The percentage of SC immediately after denervation increases when compared to normal group and later decreases in both the groups. During the process of denervation, there was an increase in IF when compared with normal group. The percentage of SC reduces significantly between the periods of denervation in both the groups. The smaller percentage of SC corresponds to higher number of IF. Besides that the number of SC decreases after denervation. As for IF, with the increase in time in normal group, the number of fibers was unaltered. However, in the experimental group, with increase in the time of denervation, the percentage of SC decreases while there is increase in the number of IF significantly. In denervated muscles for long period, there is decrease in the percentage of SC and increase in IF. Our results suggest that the period between 16th and 19th week post denervation is the best time for reinnervation of denervated muscle.

\section{Introduction}

The skeletal muscle has been the subject of studies and research in various different fields of science. Various types of pathologies may affect this tissue and there has been increasing interest in recovery of their structural and functional organization in the scientific world.

Skeletal muscle development is a highly coordinated process that involves the myogenesis and differentiation of primary myoblasts. The skeletal muscle exhibits satellite cells. The satellite cells are small myogenic cells in a quiescent state located between the sarcolemma and basal lamina of muscle fibers [1, 2]. During the extra-uterine life, these cells remain dormant, but depending on certain stimuli such as myotrauma, they get activated, ie synthesize several proteins that contribute to modify the status of the cell [3-11].

It is postulated that these cells are protagonists in the process of reconstitution of the injured muscle tissue. Disruption of the sarcolemma induce the migration of these cells to the injured area where they can blend into the muscle fibers which are still viable or position themselves in the tissue precursor cells (myotube) differentiating into muscle cells. The fusion of satellite cells with the consequent transfer of its nucleus allows an increase in protein synthesis thereby increasing the chances of recovery of this cell. On the other hand, the differentiation in myotubes contributes to the emergence of new fibers and ultimately recovering the injured area [12-15].

Neuromuscular spindles are sensory receptors, which are sensitive to stretch and tension. The modification of the muscle fibers in relation to the tension and length are the main physical parameters of muscle activity, 
which are perceivable through the proprioceptive system located deep inside the muscles and tendons [16].

The neuromuscular spindles are mechanoreceptors that are situated among the muscle fibers. These are the main sensory organ of the muscle belly, also considered as the regulatory contractile unit of muscle and is composed of intrafusal fibers (IF), surrounded by a sheath of connective tissue, containing liquid in its inside and are parallel to the extrafusal fiber (EF). The spindle is connected to the extrafusal fibers, so whenever the muscle is stretched, elongation of the spindle also takes place. The process of excitation of the neuromuscular spindle occurs when a stimulus of elongation is applied [17].

Previous studies have shown that postural muscles contain a high proportion of neuromuscular spindles [18]. Furthermore, the neuromuscular spindles are responsible for monitoring the speed and duration of stretching and detect changes in the length of the muscle. These fibers are sensitive to the velocity with which a muscle is stretched [19].

The absolute number of spindles in a muscle depends to some extent on the size of the muscle; for example, the absolute numbers of spindles in the first lumbrical and latissimus dorsi muscles in humans are 51 and 368 , respectively [20]. Therefore, in order to compare the relative richness of muscles in spindle content, the mass of muscle must be taken into account $[20,21]$.

Methods to observe the structural behavior of skeletal muscle have been used in last few decades, especially the techniques of denervation. Several studies on this regard, such as morphological and morphometric analysis of skeletal muscles at various post-denervation periods, observations of proliferation of myonuclei and satellite cells and apoptosis of muscle fibers have been conducted [22-24].

In skeletal muscle, the denervation causes in increased expression of various genes that are involved in a variety of aspects of autophagy [25]. Furthermore, denervation causes changes, which can be observed by the decrease in trophism along with increase in adipose and connective tissue in the affected muscle [26]. When there is damage to skeletal muscle, a series of processes takes place resulting in tissue repair. Muscle injury can lead to inflammation, activation of satellite cells, myogenesis, proliferation of fibroblasts and reorganization of connective tissue and extracellular matrix [26].

Slow-twitch muscles (red), like soleus for instance, when subjected to denervation produces greater muscle atrophy than in fast-twitch muscles (white), such as the Extensor digitorum longus (EDL) [4]. This atrophy due to denervation affects both the slow and fast muscle fibers, resulting in reduction of the muscle fiber diameter and muscle strength [26].

Some authors have reported a significant increase of satellite cells after denervation [27, 28], however, other studies have demonstrated that immediately after denervation, satellite cell population does not seem to change [29]. In order to collaborate in understanding the phenomena resulting from denervation in striated muscles with different morphological characteristics (soleus and EDL), denervation of these muscles in rats were performed for a long period of time, analyzing the percentage of satellite cells and the number of intrafusal fibers. Further this study also evaluates the best time period for reinnervation of muscle after experimental denervation. 


\section{Materials And Methods}

\subsection{Surgical procedure and experimental design}

All procedures were carried out in accordance with Brazilian society on Animal experimentation (COBEA) and were approved by the Animal Research Ethics committee of Bauru School of Dentistry, FOB/USP/Bauru. The experimental model consisted of seventy-two male Wistar rats (Rattus norvegicus) weighing between 180 and $200 \mathrm{~g}$. The animals were then divided into four different groups: 2 control (Soleus and EDL) and 2 denervated (Soleus and EDL).

The animals were anesthetized with an intramuscular injection of the combination of ketamine hydrochloride (Dopalen ${ }^{\circledR}$ ) and Xylazine hydrochloride (Anazedan $\AA$ ) at a dose of $0.1 \mathrm{ml} / 100 \mathrm{~g}$ of body mass. All surgeries were performed under aseptic conditions.

Initially, trichotomy of the right lateral thigh of each animal was performed. Following this, an incision between the ischial tuberosity and the greater trochanter was made to expose the sciatic nerve. Approximately $10 \mathrm{~mm}$ of the sciatic nerve was excised from its middle third. The proximal stump of the sciatic nerve was ligated, bent backwards and sutured to the adjacent muscles to prevent possible reinnervation.

All the animals which were going to be sacrificed after 4 months of surgery were re-operated at least every three months and the proximal stump was sectioned again and sutured to the adjacent muscle as described above thus aiming to prevent reinnervation of the muscles to be analyzed.

After surgery, all the animals were placed in plastic cages with a maximum of five animals per cage, with food and water "ad libitum" with light / dark cycles of 12 hours each, with controlled temperature and humidity.

In all the normal and experimental groups, muscles were dissected and removed after time intervals of 0,12 , $16,19,30$ and 38 weeks for histological analysis.

\subsection{Collection of samples}

After the experimental period the animals were again anesthetized as described above and the hind limbs were perfused via the abdominal aorta with Ringer's solution containing $1 \%$ procaine hydrochloride and 5,000 units / liter of heparin followed by $2.5 \%$ glutaraldehyde in $0.1 \mathrm{M}$ phosphate buffer.

The soleus and EDL muscles were dissected, removed and were subsequently postfixed with osmium tetroxide and embedded in 1\% epoxy resin (Araldite ${ }^{\circledR}$ ).

\subsection{Histological preparation and data collection}

The muscles collected were fixed in $10 \%$ formalin for 24 hours. The samples were then washed for 24 hours in running water and were stored in $70 \%$ alcohol for more 24 hours. For inclusion in historesin, the samples were immersed in $95 \%$ alcohol for 2 hours followed by another 4 hours in a mixture of $95 \%$ alcohol and 
historesin. After this period the material was finally immersed for 24 hours in historesin liquid. Subsequently, the samples were placed in molds and the historesin was catalyzed to enable hardening of the blocks.

\section{Satellite Cells}

Sections for electron microscopy observation were obtained from the same blocks, collected on suitable mesh grids and stained with uranyl acetate and lead citrate. Each grid has approximately 300 square-shaped holes. Were used covering Sect. 30-50 of the grid holes and made of paper in a schematic section in such low magnification. The holes were covered by Section numbered. After that, at high magnification the myonuclei and satellite cell nuclei were counted. All were considered myonuclei fiber core within myofilaments while presenting cell nuclei were taken of all the satellites within cell nuclei located beneath the basal lamina of the muscle fiber, or more precisely between the sarcolemma and the basal lamina of the striated muscle fibers. Serial sections were obtained at least $20 \mu \mathrm{m}$ in distance to avoid the possibility of counting the same myonuclues twice. An area containing at least 400 myonuclei was investigated for each muscle and the percentage of SC was calculated.

\section{Neuromuscular spindles}

For analysis of the neuromuscular spindles, transverse semi-thin sections of $1.3 \mu \mathrm{m}$ thickness were made from the middle third of each muscle and were stained with parafenildiamine (ppd). The cross sections were then assessed with the help of an Olympus ${ }^{\circledR}$ BX-50 microscope equipped with a camera (Olympus ${ }^{\circledR}$ DP-71). Photographs from each sample were taken and were analyzed with the help of computer software (Image Pro-Plus ${ }^{\circledR}$ 6.0). Intrafusal fibers from spindles of all the animals were counted and an average was taken. All muscles with signs of reinnervation such as the presence of myelinated axons or groups of myofibers incompatible with dimensions were discarded.

\subsection{Statistical analysis}

Descriptive statistics (mean, standard deviation) were calculated for all variables using the statistical package SPSS ${ }^{\circledR}$ (version 13.7, SPSS Inc.).

For the satellite cells and intrafusal fibers counts in both Soleus and EDL, we performed a comparative analysis between the groups (Normal control and Experimental) and periods of denervation using analysis of variance with two criteria and the Tukey Test. For all analysis, value $p<0.001$ were considered significant

For correlation between the number of satellite cells, intrafusal fibers and the periods of denervation, we used the Pearson correlation coefficient. For all analysis, value $p<0.05$ were considered significant.

Statistical tests were performed using the program STATISTICA® v. 5.1 (StatSoft Inc., Tulsa, USA).

\section{Results}

\subsection{Quantitative Analysis}

\section{Satellite cells}


The percentage of satellite cells in relation to myonuclei decreases with age in normal muscles, and on average there is a higher incidence of satellite cells in Soleus muscle (Fig. 3A) compared to the EDL muscle (Fig. 3B). It is also observed that the percentage of satellite cells in muscles immediately after denervation increases compared to normal muscle, especially in the EDL muscle and then decreases in both muscles from the 12th week of denervation (Fig. 3A and 3B). Another interesting observation is that during the 16th weeks of denervation of the experimental group, the percentage of satellite cells is similar to the percentage of satellite cells in the normal group, in both muscles studied (Fig. 3A and 3B). This was not seen during other time periods.

\section{Neuromuscular spindles}

The neuromuscular spindles in normal groups have on average four to five intrafusal fibers in the Soleus muscle; however the number in the denervated group increases 16 week after surgery (Fig. 3C). In the EDL muscle such change could be observed only 19 weeks after surgery (Fig. 3D).

This increase in the number of intrafusal fibers was directly proportional to the duration of denervation, ie during the progression of the denervation period of both the Soleus and EDL muscles, there was an increase in the number of intrafusal fibers, compared to the normal group (Fig. 3C and 3D).

\subsection{Statistical Analysis: Comparative (Tukey test)}

Satellite cells: Statistical analysis comparing the number of satellite cells between the periods of denervation in both the experimental and normal group in the soleus muscle shows a significant difference between most periods. No significant difference was seen between the periods: Normal 0 X 12 Denervated, Normal 16 X 19 Normal, Denervated $16 \times 30$ Normal, Denervated 19 X Normal 38 (Table 1 and Fig. 3A). 
Table 1

Comparison between groups and different periods.

\begin{tabular}{|c|c|c|c|c|c|c|c|c|c|c|c|c|}
\hline & \multicolumn{6}{|c|}{$\begin{array}{l}\text { DENERVATED GROUP } \\
\text { Weeks }\end{array}$} & \multicolumn{6}{|c|}{ NORMAL GROUP } \\
\hline & 0 & 12 & 16 & 19 & 30 & 38 & 0 & 12 & 16 & 19 & 30 & 38 \\
\hline $\begin{array}{l}\mathrm{SC} \\
\text { (Soleus) } \\
\%\end{array}$ & $\begin{array}{l}12,06 \\
\mathbf{h}\end{array}$ & $f^{9,00}$ & $e^{7,09}$ & $e^{6,98}$ & $\begin{array}{l}6,01 \\
d\end{array}$ & $\begin{array}{l}4,02 \\
\text { c }\end{array}$ & $\begin{array}{l}11,04 \\
\mathbf{g}\end{array}$ & $\begin{array}{l}12,01 \\
h\end{array}$ & $\begin{array}{l}6,03 \\
d\end{array}$ & $\begin{array}{l}4,00 \\
\text { c }\end{array}$ & $\begin{array}{l}2,03 \\
\mathbf{b}\end{array}$ & $1,00 \mathbf{a}$ \\
\hline $\begin{array}{l}\text { SC } \\
\text { (EDL) } \\
\%\end{array}$ & $8,89 \mathbf{i}$ & $\begin{array}{l}7,04 \\
\mathbf{g}\end{array}$ & $\begin{array}{l}6,01 \\
f\end{array}$ & $e^{5,00}$ & $e^{5,05}$ & $\begin{array}{l}3,02 \\
\text { c }\end{array}$ & $\begin{array}{l}8,09 \\
h\end{array}$ & $\mathbf{j}^{11,05}$ & $\mathbf{e}^{4,96}$ & $\begin{array}{l}3,94 \\
d\end{array}$ & $\begin{array}{l}2,05 \\
\mathbf{b}\end{array}$ & $\begin{array}{l}1,04 \\
\mathbf{a}\end{array}$ \\
\hline $\begin{array}{l}\text { IF } \\
\text { (Soleus) } \\
n^{0}\end{array}$ & $\begin{array}{l}4,32 \\
\mathbf{a}\end{array}$ & $\begin{array}{l}4,00 \\
\mathbf{a}\end{array}$ & $\begin{array}{l}4,24 \\
\mathbf{a}\end{array}$ & $\begin{array}{l}4,34 \\
\mathbf{a}\end{array}$ & $\begin{array}{l}4,62 \\
a b\end{array}$ & $\begin{array}{l}4,64 \\
a b\end{array}$ & $\begin{array}{l}4,69 \\
a b\end{array}$ & $\begin{array}{l}5,34 \\
\text { b }\end{array}$ & $\begin{array}{l}6,70 \\
\mathbf{c}\end{array}$ & $\begin{array}{l}6,71 \\
\text { c }\end{array}$ & $\begin{array}{l}7,69 \\
d\end{array}$ & $\begin{array}{l}8,07 \\
\text { d }\end{array}$ \\
\hline $\begin{array}{l}\text { IF } \\
\text { (EDL) } \\
n^{0}\end{array}$ & $\begin{array}{l}4,64 \\
a b\end{array}$ & $\begin{array}{l}4,68 \\
\text { b }\end{array}$ & $\begin{array}{l}4,34 \\
a b\end{array}$ & $\begin{array}{l}4,00 \\
a b\end{array}$ & $\begin{array}{l}4,60 \\
a b\end{array}$ & $\begin{array}{l}4,66 \\
\text { b }\end{array}$ & $\begin{array}{l}3,87 \\
\mathbf{a}\end{array}$ & $\begin{array}{l}4,64 \\
\text { b }\end{array}$ & $\begin{array}{l}5,73 \\
\mathbf{c}\end{array}$ & $\begin{array}{l}\text { 6,09 } \\
\text { c }\end{array}$ & $\begin{array}{l}7,01 \\
d\end{array}$ & $\begin{array}{l}7,97 \\
\mathbf{e}^{-9}\end{array}$ \\
\hline $\begin{array}{l}\text { Groups w } \\
\text { variance }\end{array}$ & $\begin{array}{l}h \text { the sa } \\
\text { NOVA) }\end{array}$ & nd Tul & y's tes & $\begin{array}{l}\text { רo sigr } \\
p<0 \text {. }\end{array}$ & & & betwe & them & & & analy & s of \\
\hline SC (satell & e cells), & $=($ intra & usal fil & & & & & & & & & \\
\hline
\end{tabular}

In the EDL muscle, statistically significant differences were seen between all the groups except between Denervated 16, Normal 19 and Normal 30, where the percentage of satellite cells were in close proximity to each other. Comparison between the rests of the groups showed statistically significant results (Table 1 and Fig. 3B).

\section{Neuromuscular spindles}

Through statistical analysis it can be observed that in Soleus muscle, there is no significant difference in the number of Intrafusal fibers between the different intervals of the normal group (Table 1 and Fig. 3C).

While in the denervated group, there was no statistically significant difference between the groups: Denervated 0 X 12 Denervated, Denervated 16 X 19 Denervated and Denervated 30 X 38 Denervated (Table 1 and Fig. 3C).

However, when comparing the normal group with the experimental, statistically significant difference between all periods were seen except between Normal 0 X 0 Denervated (Table 1 and Fig. 3C). 
In EDL muscle, the statistical analysis shows similar results to that of the soleus muscle, ie, no significant difference in the number of Intrafusal fibers between the different intervals of the normal group were seen (Table 1 and Fig. 3D).

Meanwhile in the denervated group, statistically significant difference was not seen between the groups Denervated 16 and 19 (Table 1 and Fig. 3D).

When compared with the normal group, there were no statistically significant differences between: Normal 0 X 0 Denervated and Denervated 12 X 12 Normal (Table 1 and Fig. 3D).

\subsection{Statistical Analysis: Correlation (Pearson Test)}

Correlating of the percentage of satellite cells with the number of intrafusal fibers, there was a statistically significant negative correlation to both muscles examined (soleus and EDL) only in the denervated group, ie, the more reduced the number of satellite cells is, greater the number of IF (Table 2, Fig. 4C and 4D).

Table 2

Correlation of percentage of satellite cells with the number of intrafusal fibers.

\begin{tabular}{|lll|}
\hline & NORMAL GROUP & DENERVATED GROUP \\
\hline SC $\times$ IF (Soleus) & $r=-0,30$ & $r=-0,93$ \\
& $p=, 107$ & $p=, 000^{*}$ \\
\hline SC IF (EDL) & $r=0,06$ & $r=-0,87$ \\
\hline & $p=, 744$ & $p=, 000^{*}$ \\
\hline Pearson's correlation coeficiente. ${ }^{*}$ significant $p<0,005$ \\
\hline$r=-$ (negative correlation coefficient) \\
\hline SC (satellite cells), IF (intrafusal fibers) \\
\hline
\end{tabular}

In the control group it was found a negative statistical correlation between denervation time and the number of satellite cells and intrafusal fibers in both of studied muscles. It means that when the denervation time is increased the SC number decreases. On the other hand when the denervation time increases the number of IF remains the same (Table 3, Fig. 4A and 4B). 
Table 3

Correlation of different experimental TIMES periods with percentage

of satellite cells and number of intrafusal fibers (Normal group).

\begin{tabular}{|l|llll|}
\hline & $\begin{array}{l}\text { CS Soleus } \\
(\%)\end{array}$ & $\begin{array}{l}\text { CS EDL } \\
(\%)\end{array}$ & $\begin{array}{l}\text { IF Soleus } \\
\left(n^{\circ}\right)\end{array}$ & $\begin{array}{l}\text { IF EDL } \\
\left(n^{\circ}\right)\end{array}$ \\
\hline $\begin{array}{l}\text { EXPERIMENTAL } \\
\text { TIME periods }\end{array}$ & $r=-0,97$ & $r=-0,96$ & $r=0,35$ & $r=0,02$ \\
\hline & $p=, 000^{*}$ & $p=, 000^{*}$ & $p=, 056$ & $p=, 914$ \\
\hline Pearson's correlation coeficiente. *significant $p<0,005$ & \\
\hline$r=-$ (negative correlation coefficient) & \\
\hline$r=+($ positive correlation coefficient) & \\
\hline SC (satellite cells), IF (intrafusal fibers) \\
\hline
\end{tabular}

Furthermore, in the experimental group when compared with the time of denervation, satellite cells demonstrated a negative correlation while the correlation was positive with intrafusal fibers (Table 4, Fig. 4C and 4D).

Table 4

Correlation of different experimental TIMES periods with percentage of satellite cells and number of intrafusal fibers (Denervated group).

\begin{tabular}{|c|c|c|c|c|}
\hline & $\begin{array}{l}\text { CS Soleus } \\
(\%)\end{array}$ & $\begin{array}{l}\text { CS EDL } \\
(\%)\end{array}$ & $\begin{array}{l}\text { IF Soleus } \\
\left(n^{\circ}\right)\end{array}$ & $\begin{array}{l}\text { IF EDL } \\
\left(n^{\circ}\right)\end{array}$ \\
\hline $\begin{array}{l}\text { EXPERIMENTAL } \\
\text { TIMES periods }\end{array}$ & $r=-0,89$ & $r=-0,82$ & $r=0,94$ & $r=0,96$ \\
\hline & $p=, 000^{\star}$ & $p=, 000^{\star}$ & $p=, 000 *$ & $\mathrm{p}=, 000^{*}$ \\
\hline \multicolumn{5}{|c|}{ Pearson's correlation coeficiente. *significant $p<0,005$} \\
\hline \multicolumn{5}{|c|}{$r=-$ (negative correlation coefficient) } \\
\hline \multicolumn{5}{|c|}{$r=+($ positive correlation coefficient $)$} \\
\hline SC (satellite cells & IF (intrafusa & fibers) & & \\
\hline
\end{tabular}

\section{Discussion}

In order to determine the most appropriate period to attempt recovery of a nerve and the corresponding innervated muscle, it is important to consider the changes that occur in both of them. 
In nerve fibers which have undergone axotomy, it is known that the production of Nerve Growth Factor (NGF) reaches a maximum level after 24 hours and high levels of NGF are maintained at least two weeks after injury. The denervated muscle fibers however suffer atrophy and gradually lose tissue mass [22].

In muscle tissue denervated for a longer period of time i.e over 25 weeks, there is a significant reduction in the number of satellite cells [22]. Therefore muscles with a longer period of denervation do not present conditions for a possible reinnervation.

This was supported by another study [30] who conducted denervation of the pectoralis muscle of frog and observed, after nearly four years, the complete absence of muscle fibers.

Studies have been conducted evaluating the optimum time period for reinnervation in muscles with sectioned motor nerves. Some findings have suggested that the best time to receive new contact of motor nerve it would be between 12 and 16 weeks after surgery [23]. However, when there is no tissue loss, the faster the nerve repair attempt, better is the regeneration [23].

Classically, attempts of reinnervation of muscle would be performed as soon as possible. However on analyzing denervated muscles, muscle fibers are seen morphologically with characteristics of young fibers only after 12 weeks of denervation. The nerves play an important role in the modulation of such muscle fibers by changing its constitution or by modulating the different fiber types to better reach the functional demands of the muscle. Therefore in observing the natural development of striated skeletal muscles, a delay of several weeks may be more accurate than the immediate attempt of reinnervation, in particular if there is nerve tissue loss.

Recently, studies in rats have revealed that the gradual increase in muscle activity after targeted muscle reinnervation (TMR) takes place within 4 weeks. In comparison to normal muscle, the electromyography activity of the reinnervated muscle indicates an innerveration between the transferred nerve and the targeted muscle within four weeks after TMR surgery. In cases of amputees after TMR surgery, the muscle needs a long time to reinnervate and heal [31].

In this study, we conducted experimental lesions in rat sciatic nerve (with tissue loss) without recovery. The muscles chosen for morphological analysis of its recovery were the Soleus and EDL. The soleus muscle is considered as a postural muscle, which is rich in red fibers (type SO and FOG), and therefore more homogeneous, while EDL on the other hand is rich in white fibers (FG).

The present study demonstrated that the percentage of satellite cells decreases in soleus and EDL after denervation. The initial reaction in the EDL muscle after denervation is an increase in the percentage of satellite cells for a short period and then continues to decrease to near zero after 30 weeks. The increase in the percentage of satellite cells in soleus muscle also occurred in a short period of time after surgery.

The satellite cell population represents considerable potential for the postnatal growth of skeletal muscle [32] and the amount of satellite cells is dependent on nerve or muscle activity mediated by innervation. Their percentage is normal in reinnervated and regenerated muscles [33], but declines rapidly during regeneration deprived of innervation [34]. The events that occur in a denervated muscle can be described as slow and not

Page $11 / 19$ 
synchronous [30,34,35]. Such events also affect the intrafusal fibers, where there is increase in their number [36].

We believe that the poor recovery of muscle strength after a significant delay in the surgical repair of the motor nerve is not only due to prevention of axonal regeneration through endoneurium, but also due to the decline of satellite cells in the muscle while it remained denervated for a long period.

Furthermore, our results show that the percentage of satellite cells in denervated muscle is similar to the percentage of satellite cells in normal muscle between the 16th and 19th week post-surgery.

From the results obtained in this research and with the aid of the literature it may be appropriate to infer that the optimum time period for reinnervation of a denervated muscle is between 16th and 19th weeks after surgery. During this time, the denervated muscle contains a similar amount of satellite cells to normal muscle, ultimately favoring muscle recovery.

In this study, the muscles in all the normal groups at the 38th week showed on an average 4 to 5 Intrafusal fiber. However, in the denervated groups of both the soleus and EDL muscles there is a statistically significant increase in the number of intrafusal fibers, directly proportional to the experimental time.

However, studies in humans on age related changes of the proprioceptive system with focus on muscle spindle showed a loss of intrafusal fibers per neuromuscular spindle which theoretically may be related to its own degeneration process [37].

Furthermore, the authors also suggest that these aforementioned changes related to aging are connected to an increased thickness of the connective capsule of the neuromuscular spindle. This is contrary to what we observed in our work, where only in the denervated groups; the connective capsule of neuromuscular spindles was altered showing a thickening of tissue around the intrafusal fibers.

This study demonstrates that there is an increase in the number of intrafusal fibers in the denervated group over a long period of time (38 weeks), where this increase is inversely proportional to the percentage of satellite cells. This correlation is considered statistically significant, suggesting that the increase of intrafusal fibers may be an attempt to maintain the muscular proprioceptive function.

We emphasize that this research can contribute to other studies on recovery of an injured muscle, as it suggests that the optimum period of reinnervation of a denervated muscle is between 16th and 19th week after denervation, during which the percentage of the satellite cells is similar that of the normal muscles. The results also demonstrate that with the increase in the period of denervation, the number of intrafusal fibers increases, suggesting that even during degeneration of muscle, intrafusal fibers increase in number in order to maintain proprioceptive and sensory functions.

In summary, further research is necessary to complement our findings in developing an ideal time frame for reinnervation for recovery of injured muscle and motor nerves.

\section{List Of Abbreviations}

Page 12/19 
SC - Satellite cells

IF - intrafusal muscle fibers

EF - Extrafusal fiber (EF)

EDL - Extensor digitorum longus

NGF - Nerve Growth Factor

TMR - Targeted muscle reinnervation

\section{Declarations}

\section{Ethics approval consent to participate}

The present study was approved by the Ethics Committee on Animal Education and Research - Protocol $\mathrm{n}^{\circ}$ 022/2009 - of the University of São Paulo, Faculty of Odontology of Bauru / Bauru / São Paulo / Brazil.

\section{Consent for publication}

Not applicable

\section{Availability of data and materials}

The datasets generated and/or analysed during the current study are available in the Biblioteca Digital USP Teses e Dissertações repositor. DOI: 10.11606/T.25.2012.tde-05112012-185039

\section{Competing interests}

The authors declare that they have no competing interests

\section{Funding}

This work was supported by the Institutional CAPES.

\section{Authors' contributions}

A.L.S. researcher in charge of the research and its progress; C.G.S.M. assisted in the surgical procedures and was in charge of the daily care of the animals; F.J.A, B.S.S, J.V.T.C.S. and G.L.T. responsible for the daily care of animals and bibliographical survey; C.C.B., R.L.B. and M.A.M. he took part in the surgical procedures composing the standardization of the same ones; J.C.A. and A.C.R. teacher in charge of the research (supervision and guidance).

\section{Acknowledgements}

The authors would like to thank Professor Dr. José Roberto Pereira Lauris for the statistical analysis of the data 


\section{References}

1. Ehrhardt J, Brimah K, Adkin C, Partridge T, Morgan J. Human muscle precursor cells give rise to functional satellite cells in vivo. Neuromuscul Disord. 2007;17(8):631-8.

2. Morgan JE. Satellite cells and skeletal muscle regeneration. Neuromuscul Disord. 2011;21(9-10):640.

3. Mouly V, Edom F, Barbet JP, Butler-Browne GS. Plasticity of human satellite cells. Neuromuscul Disord. 1993;3(5-6):371-7.

4. Rodrigues AC, Geuna S, Rodrigues SPM, Silva MD, Aragon FF. Satellite cells and myonuclei in neonatally denervated rat muscle. Ital J Anat Embryol. 2002;107(1):51-6.

5. Hill M, Wernig A, Goldspink G. Muscle satellite (stem) cell activation during local tissue injury and repair. J Anat. 2003;203(1):89-99.

6. Hill M, Goldspink G. Expression and splicing of the insulin-like growth factor gene in rodent muscle is associated with muscle satellite (stem) cell activation following local tissue damage. J Physiol. 2003;549(Pt 2):409-18.

7. Partridge T. The Role of Satellite Cells and Circulating Stem Cells in Regeneration of Skeletal Muscle. Basic Appl Myol. 2003;13(6):277-80.

8. Anderson JE. The satellite cell as a companion in skeletal muscle plasticity: currency, conveyance, clue, connector and colander. J Exp Biol. 2006;209(Pt 12):2276-92.

9. Beccafico S, Puglielli C, Pietrangelo T, Bellomo R, Fanò G, Fulle S. Age-dependent effects on functional aspects in human satellite cells. Ann NY Acad Sci. 2007;1100:345-52.

10. Tajika Y, Sato M, Murakami T, Takata K, Yorifuji H. VAMP2 is expressed in muscle satellite cells and upregulated during muscle regeneration. Cell Tissue Res. 2007;328(3):573-81.

11. Singhal N, Martin PT. A role for Galgt1 in skeletal muscle regeneration. Skelet Muscle. 2015;5(3):1-16.

12. Trensz F, Lucien F, Couture V, Söllrald T, Drouin G, Rouleau AJ, et al. Increased microenvironment stiffness in damaged myofibers promotes myogenic progenitor cell proliferation. Skelet Muscle. 2015;5(5):1-16.

13. Vitello L, Radu C, Malerba A, Segat D, Cantini M, Carraro U, et al. Enhancing Myoblast Proliferation by Using Myogenic Factors: A Promising Approach for Improving Fiber Regeneration in Sport Medicine and Skeletal Muscle Diseases. Basic Appl Myol. 2004;14(1):45-51.

14. Dreyer HC, Blanco CE, Sattler FR, Schroeder ET, Wiswell RA. Satellite cell numbers in young and older men 24 hours after eccentric exercise. Muscle Nerve. 2006;33(2):242-53.

15. Baker BA, Mercer RR, Geronilla KB, Kashon ML, Miller GR, Cutlip RG. Impact of repetition number on muscle performance and histological response. Med Sci Sports Exerc. 2007;39(8):1275-81.

16. Bolocan A, Quijano-Roy S, Seferian AM, Baumann C, Allamand V, Richard P, et al. Congenital muscular dystrophy phenotype with neuromuscular spindles excess in a 5-year-old girl caused by HRAS mutation. Neuromuscul Disord. 2014;24(11):993-8.

17. Bani D, Bergamini M. Ultrastructural abnormalities of muscle spindles in the rat masseter muscle with malocclusion-induced damage. Histol Histopathol. 2002;17(1):45-54. 
18. Elashry MI, Otto A, Matsakas A, El-Morsy SE, Jones L, Anderson B, et al. Axon and muscle spindle hyperplasia in the myostatin null mouse. J Anat. 2011;218(2):173-84.

19. Matthews PBC. The response of de-efferented muscle spindle receptors to stretching at different velocities. J Physiol. 1963;168:660-78.

20. Amonoo-Kuofi HS. The density of muscle spindles in the medial, intermediate and lateral columns of human intrinsic postvertebral muscles. J Anat. 1983;136(Pt 3):509-19.

21. Banks RW. An allometric analysis of the number of muscle spindles in mammalian skeletal muscles. $J$ Anat. 2006;208(6):753-68.

22. Rodrigues AC, Schmalbruch $\mathrm{H}$. Satellite cells and myonuclei in long-term denervated rat muscles. Anat Rec. 1995;243(4):430-7.

23. Rodrigues AC, Dolfini MIM, Geuna S, Andreo JC, Rodrigues SPM. Apoptosis in long-term denervated rat skeletal muscle. Braz J morphol Sci. 2005;22(4):151-6.

24. Rodrigues AC, Andreo JC, Rodrigues SPM. Myonuclei and satellite cells in denervated rat muscles: an electron microscopy study. Microsurgery. 2006;26(5):396-8.

25. Vainshtein A, Desjardins EM, Armani A, Sandri M, Hood DA. PGC-1 a modulates denervation-induced mitophagy in skeletal muscle. Skelet Muscle. 2015;5(9):1-17.

26. Minamoto VB. Effect of denervation on skeltal muscle: a review. Fisioter Mov. 2007;20(3):63-9.

27. Murray MA, Robbins N. Cell proliferation in denervated muscle: identity and origin of dividing cells. Neuroscience. 1982;7(7):1823-33.

28. Mcgeachie JK. Sustained cell proliferation in denervated skeletal muscle of mice. Cell Tissue Res. $1989 ; 257(2): 455-7$.

29. Snow MH. A quantitative ultrastructural analysis of satellite cells in denervated fast and slow muscles of the mouse. Anat Rec. 1983;207(4):593-604.

30. Anzil AP, Wernig A. Muscle fibre loss and reinnervation after long-term denervation. J Neurocytol. $1989 ; 18(6): 833-45$.

31. Zhou H, Yang L, Zhang L, Wu F, Huang J, Li G. Using wavelet analysis to reveal the muscle functional recovery following nerve reinnervation in a rat model. Conf Proc IEEE Eng Med Biol Soc 2014; 25492552.

32. Brown SC, Stickland NC. Satellite cell content in muscles of large and small mice. J Anat. 1993;183(Pt 1):91-6.

33. Schultz E. A quantitative study of satellite cells in regenerated soleus and extensor digitorum longus muscles. Anat Rec. 1984;208(4):501-6.

34. Schmalbruch H, Lewis DM. A Comparison of the morphology of denervated with aneurally regenerated soleus muscle of rat. J Muscle Res Cell Motil. 1994;15(3):256-66.

35. Schmalbruch H, AL-Amood WS, Lewis DM. Morphology of long-term denervated rat soleus muscle and the effect of chronic electrical stimulation. J Physiol. 1991;441:233-41.

36. Schröder JM. The fine structure of de- and reinnervated muscle spindles. II. Regenerated sensory and motor nerve terminals. Acta Neuropathol. 1974;30(2):129-44. 
37. Shaffer SW, Harrison AL. Aging of the Somatosensory System: A Translational Perspective. Phys Ther. 2007;87(2):193-207.

\section{Figures}

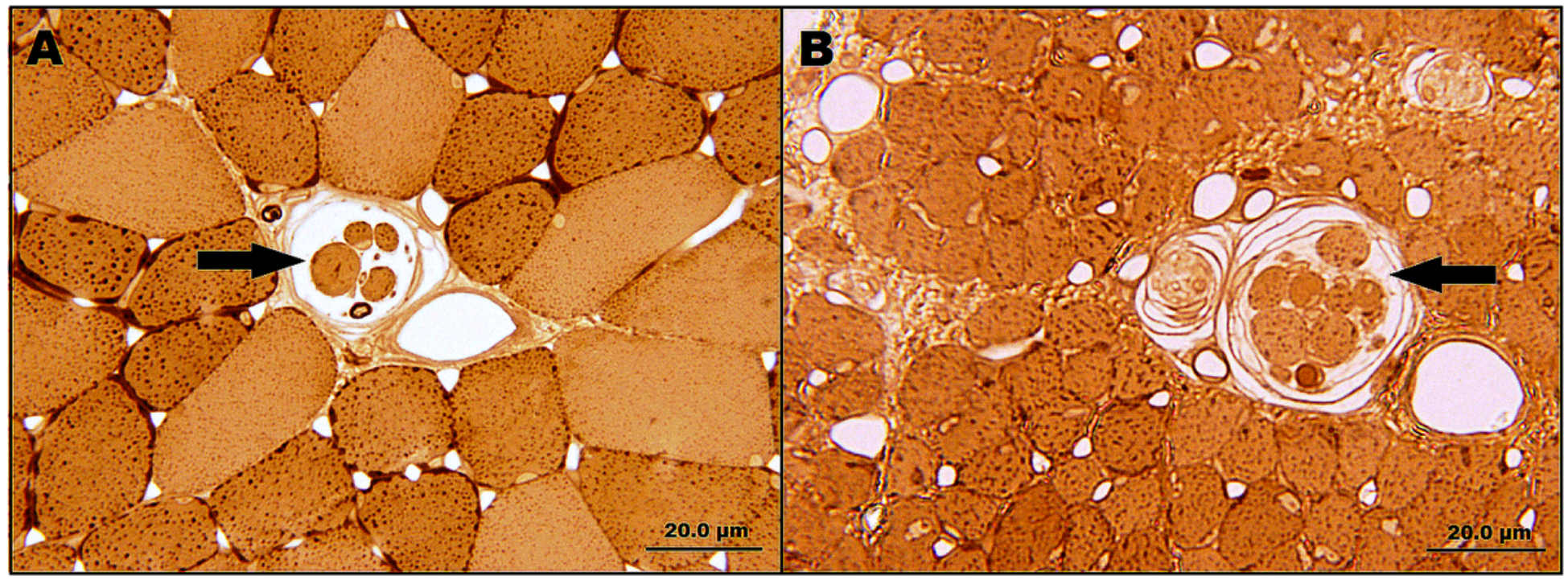

\section{Figure 1}

Optical microscopy of Transverse sections of Soleus muscle (mag. X400). (A): Black arrow - Neuromuscular spindle is composed of $4 \mathrm{IF}$ in normal muscle (0 weeks). (B): Black arrow - Significant increase in IF number is noticed and is composed of $8 \mathrm{IF}$ in denervated muscle (38 weeks). Note the evident signs of muscle atrophy. 


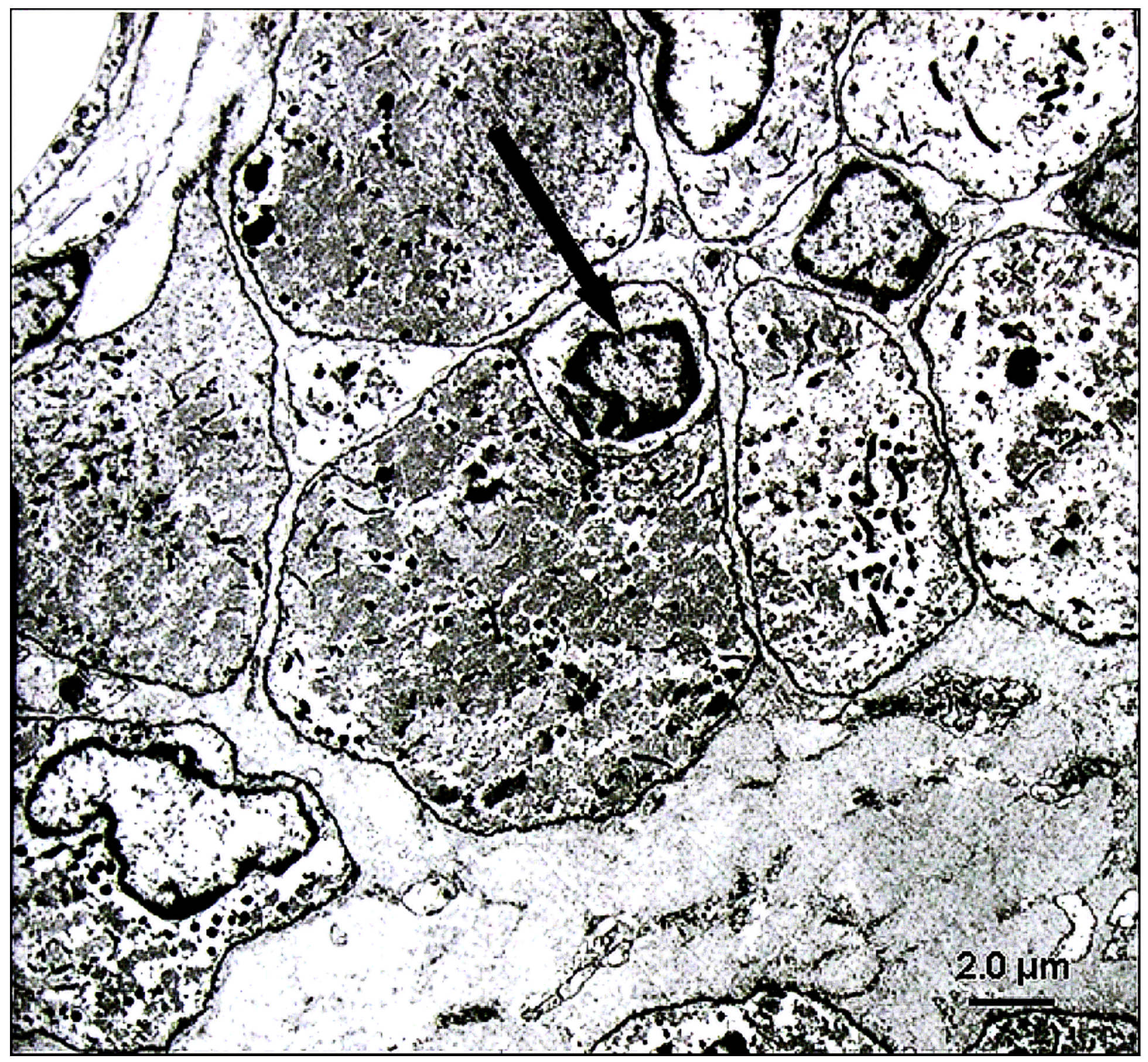

Figure 2

Transmission electron micrographs of transverse sections of EDL muscle (mag. X2000). Black arrow Quiescent muscle satellite cell. 
$\mathbf{A}$

Satellite Cell - Soleus

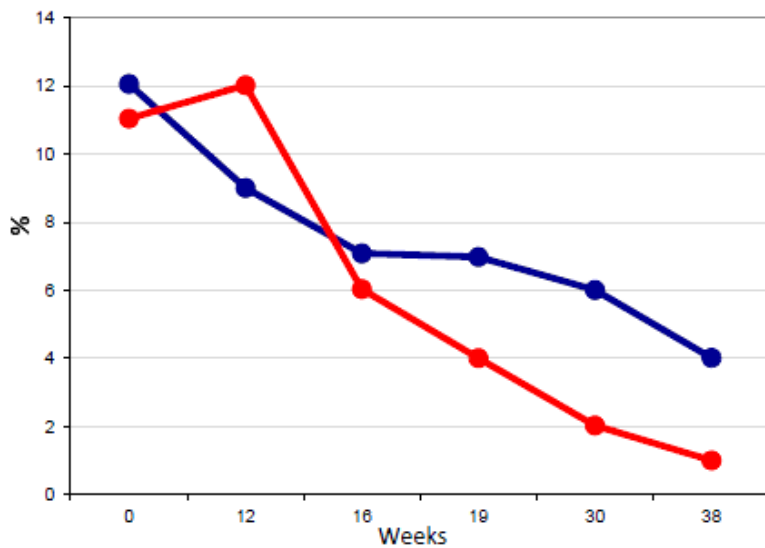

C

IF - Soleus

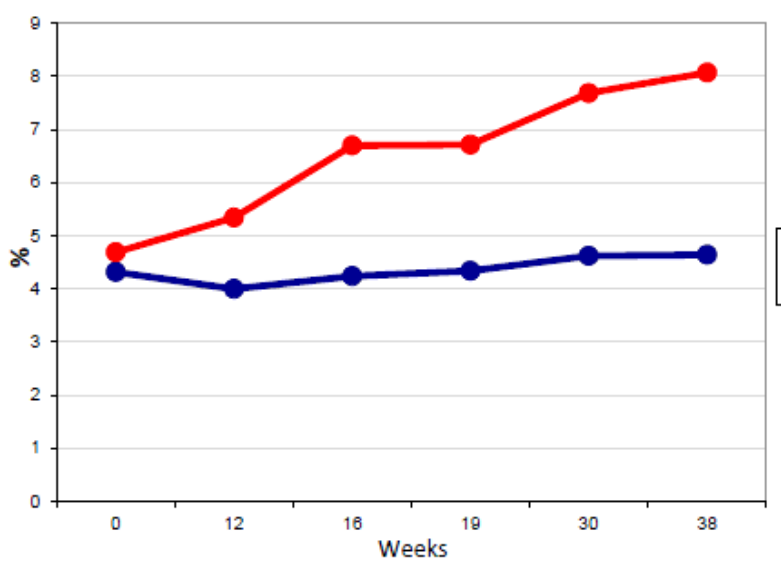

B Satellite Cell - EDL

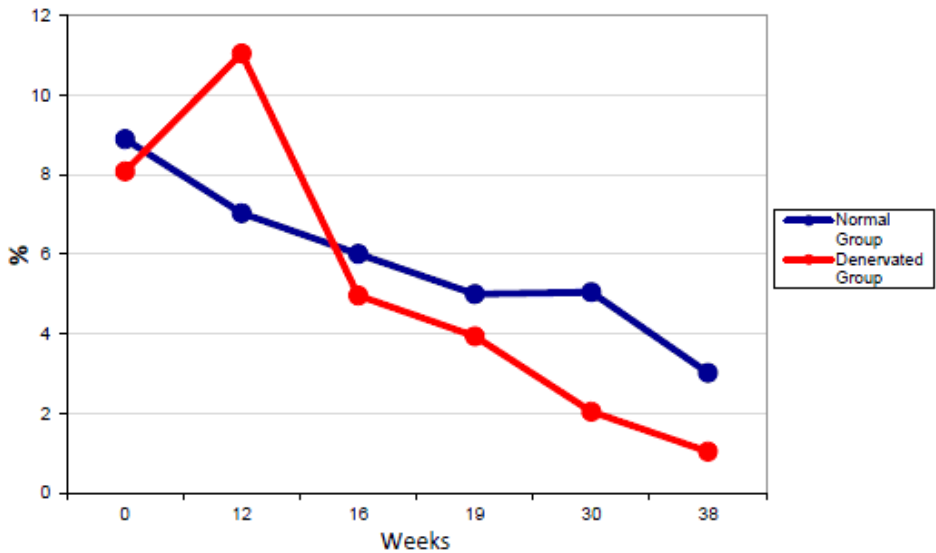

D IF-EDL

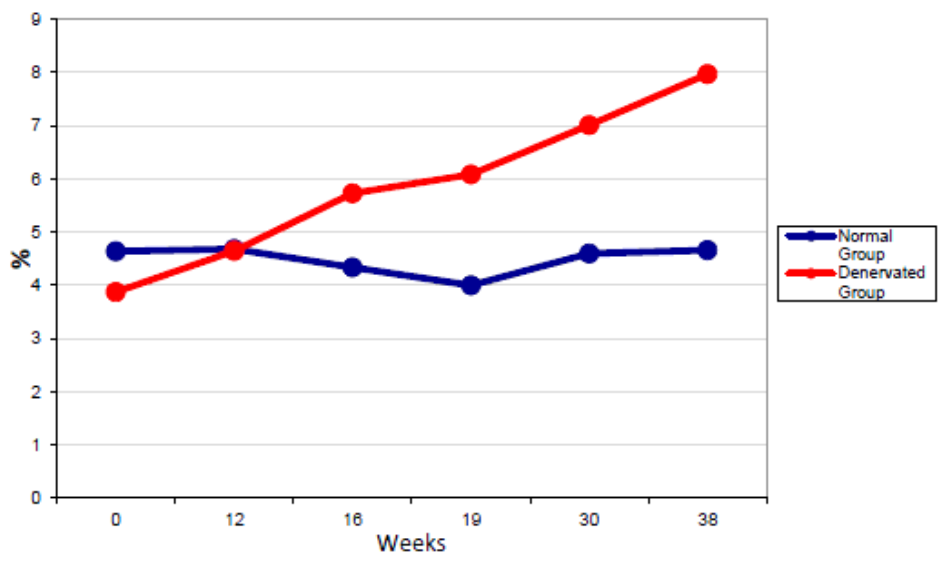

Figure 3

Line graph showing percentage of satellite cells in Soleus muscle (A), percentage of satellite cells in EDL muscle (B), number of Intrafusal fiber in Soleus muscle (C) and number of Intrafusal fiber in EDL muscle (D). 

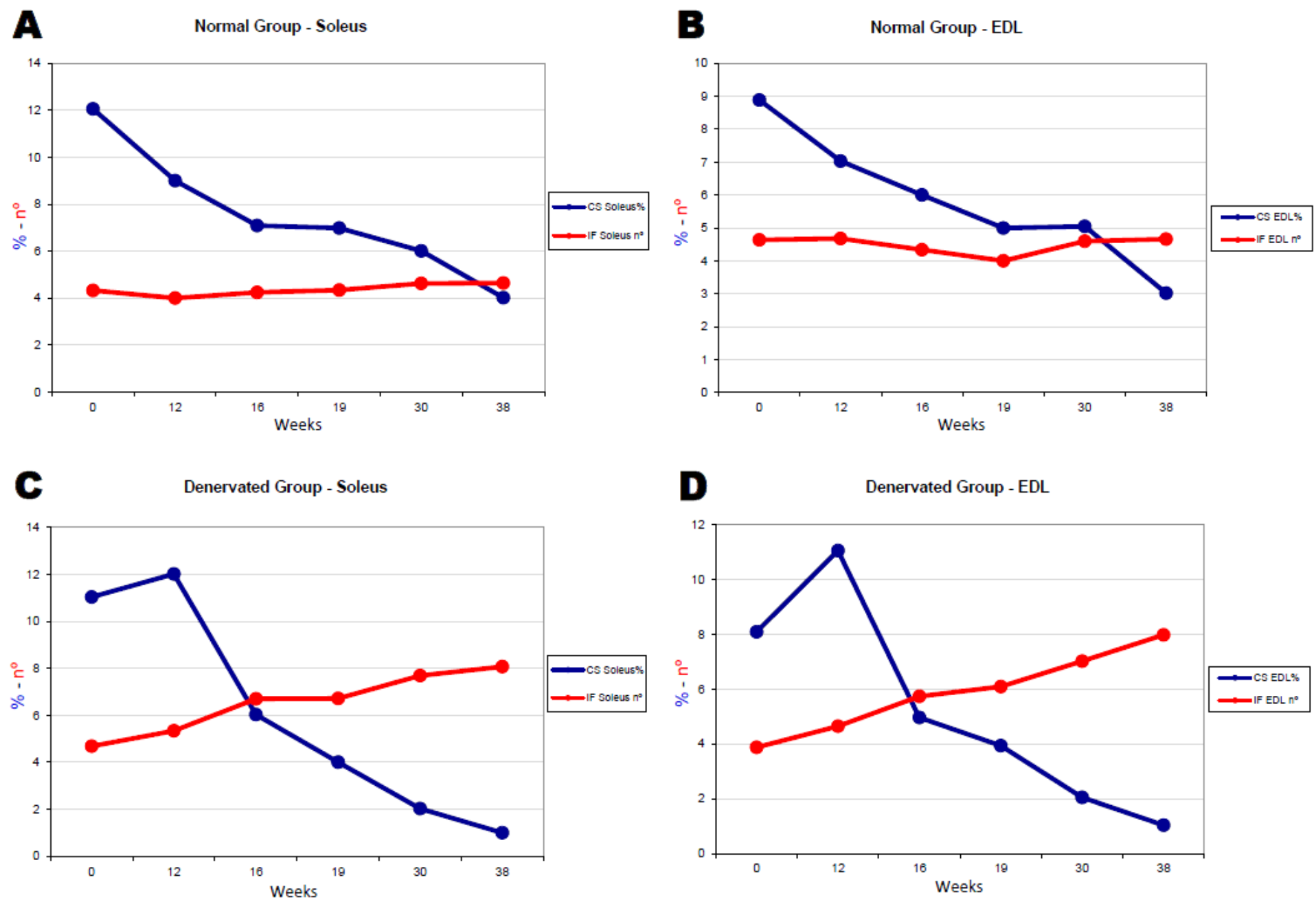

Figure 4

Line graph showing correlation of the percentage of satellite cells and number of IF in Normal group of Soleus muscle (A) and EDL muscle (B); correlation of the percentage of satellite cells and number of IF in Denervated group of Soleus muscle (C) and EDL muscle (D). 